\title{
Evaluation of Punica granatum Peels Extracts and its Phenolic, Alkaloid and Terpenoid Constituents Against Chemically Induced Diarrhoea in Rats
}

\section{Orooba Mohammed Saeed Ibrahim*, Muhammad Muslih Shwaysh}

Department of Physiology and Pharmacology, College of Veterinary Medicine, Baghdad University, Baghdad, Iraq.

\begin{abstract}
The present study was carried out to investigate the antidiarrhoeal activity of aqueous extract of peel of Punica granatum fruit and crude phenols, alkaloids, terpenoid extract in vivo by inducing diarrhoea in rats by oral administration of castor oil, enteropooling and small intestinal transit models in rats. The weight and volume of intestinal fluid induced by castor oil were studied by enteropooling method. Standard drug diphenoxylate $(5 \mathrm{mg} / \mathrm{kg}$, orally) was significantly reduced fecal output and frequency of droppings whereas crude phenols, alkaloids and aqueous extract, (at the doses of 20,40 and $400 \mathrm{mg} / \mathrm{kg}$ orally respectively) significantly $(\mathrm{P}<0.001)$ reduced the castor oil induced frequency and consistency of diarrhoea and enteropooling. The gastrointestinal transit rate was expressed as the percentage of the longest distance travelled by the charcoal by the total length of the small intestine. Crude phenols, alkaloids and aqueous extract at the doses of 20,40 and $400 \mathrm{mg} / \mathrm{kg}$ significantly inhibited $(\mathrm{P}<0.001)$ the castor oil induced charcoal meal transit. The crude phenols, alkaloids and aqueous extract of Punica granatum peel showed marked reduction in the number of diarrhoea stools and the reduction in the weight and volume of the intestinal contents, as well as a higher reduction in intestinal transit. Results obtained to establish the efficacy and substantiate the folklore claim as anti-diarrhoeal agent. Further studies are needed to understand the complete mechanism of antidiarrhoeal action of Punica ranatum.
\end{abstract}

Keywords | Antidiarrhoeal activity, Punica granatum, Phenols, Alkaloid

Editor | Kuldeep Dhama, Indian Veterinary Research Institute, Uttar Pradesh, India.

Received | November 14, 2015; Revised | February 20, 2016; Accepted | February 27, 2016; Published | March 12, 2016

*Correspondence | Orooba Mohammed S Ibrahim, Department of Physiology and Pharmacology, College of Veterinary Medicine, Baghdad University, Baghdad, Iraq; E-mail: oroobam2000@gmail.com

Citation | Ibrahim OMS, Shwaysh MM (2016). Evaluation of Punica granatum peels extracts and its phenolic, alkaloid and terpenoid constituents against chemically induced diarrhoea in rats. Adv. Anim. Vet. Sci. 4(3): 161-168.

DOI | http://dx.doi.org/10.14737/journal.aavs/2016/4.3.161.168

ISSN (Online) | 2307-8316; ISSN (Print) | 2309-3331

Copyright ( $\odot 2016$ Ibrahim and Shwaysh. This is an open access article distributed under the Creative Commons Attribution License, which permits unrestricted use, distribution, and reproduction in any medium, provided the original work is properly cited.

\section{INTRODUCTION}

$\mathrm{D}$ iarrhoea has long been recognized as one of the most important health problems in the developing countries. Diarrhoea is the passage of abnormal liquid or unformed stool at an increased frequency. Infectious agents, certain medications, plant and animal toxins, gastrointestinal disorders, and substances that increase gastrointestinal tract secretions may cause it. It can also be caused by the ingestion of poorly absorbable materials, or inflammatory and dysmotility problems of the gastrointestinal tract (Palombo, 2006; Meite et al., 2009). Secretary diarrhoea is the most dangerous symptom of gastrointestinal problems and is associated with excessive defecation and stools being of abnormally loose consistency. It thus becomes important to identify and evaluate commonly available natural drugs as an alternative to currently used antidiarrhoeal drugs, which are not completely free from adverse effects (World Health Organization, 1996).

Although currently used drugs are important in the management of diarrhoea, they are still linked with adverse effects and contraindications. For instance, racecadotril and loperamide are used to treat secretory diarrhoea but they produce bronchospasm, vomiting and fever. Moreover, some are contraindicated in children below 6 years of age (loperamide) and intestinal obstruction (Thankurta et al., 2007). From a long time ago, plant kingdom played an 
important role as medicinal plants that provide a potential sources for treatment of antidiarrhea (Palombo, 2006).

Pomegranate (Punica granatum L.) has been used in the folk medicine of many cultures, especially in the Middle East (Gurib-Fakim, 2006). Edible parts of pomegranate fruit represent $52 \%$ of the total fruit weight (E1-Nemr et al., 1990). The non edible part called pomegranate peel extract or husk extract is primarily composed of alkaloids and polyphenols, which composed from anthocyanidins, pelargonidin, ellagotannins, gallic acid, ellagic acid, psuedopelletierine and isopelletierine. (Zakir, 2005; Navindra et al., 2006; Arun and Singh, 2012). Extracts of the bark, leaves, immature fruit and fruit rind have been given to halt diarrhoea, dysentery and hemorrhages (Ghani, 2003; Agunu et al., 2011). It is necessary to establish scientific evidences for therapeutic use of such traditional medicinal plants, as it may potentially be useful source of new effective therapies in the drug development process. Hence, this study aimed at evaluating the traditional claim of antidiarrhoeal and antisecretory effect of aqueous extract of peel of P. granatum and its acute toxicity in rat model.

\section{MATERIALS AND METHODS}

\section{Preparation of Crude Alueous Extract}

Aqueous extraction of the Punica granatum peels was carried out by using (boiled distilled water) which is considered as very effective in extracting the active ingredients of the plant according to method described by (Qnais et al. 2007). A quantity of $150 \mathrm{~g}$ plant peels powder was put inside the flask with $3000 \mathrm{ml}$ of distilled water and boiled for $15 \mathrm{~min}$ with progressive stirring. The solution obtained was filtered through a filter paper. After that, the extract was dried by using an electric oven at temperature $30-35^{\circ} \mathrm{C}$. The dry extract was placed in an incubator under $38-40^{\circ} \mathrm{C}$ for complete dryness of the sample. The final extract was kept frozen at $-20^{\circ} \mathrm{C}$ until use.

\section{Extraction of Active Ingredient IN}

\section{Pomegranate Peels Alkaloids}

The extract was prepared according to the method of Harborne (1984). A quantity of $100 \mathrm{~g}$ of plant powder was homogenized in electrical blender with $350 \mathrm{ml}$ of (4:1) ethanol: disttile water the sample was filtered through muslin and then through a filter paper in Bouknner funnel, then acidified by drops of ( $2 \%$ sulphuric acid) until the $\mathrm{pH}$ level dropped between 1 and 2 . The solution was re-extracted with chloroform 3 times in the separating funnel until we got two layers; the upper one was neglected and the lower one was used. 2-3 drops of concentrated ammonium hydroxide were added to this layer until the $\mathrm{pH}$ became between 9 and 10. Then the solution was again extracted in the separation funnel with (1:3) chloroform: methanol twice and once with chloroform alone. After that the solu- tion was separated into two layers; the upper layer (solvent) was neglected and the lower layer was evaporated in a rotary evaporator at $40^{\circ} \mathrm{C}$ for (1-2) hours, then oven dried until it turned into powder and the powder was kept in the refrigerator until use.

\section{Phenols}

Phenols were extracted according to Ribereau-Gayon (1972) and Harborne (1984). A quantity of $200 \mathrm{~g}$ of plant powder was divided into 2 equal portions, one was mixed with $300 \mathrm{ml}$ of D.W. and the other one was mixed with 300 $\mathrm{ml}$ of $1 \%$ Hydrochloric acid. Then samples were homogenized in electric shaker for 5 minutes. The two mixtures were transferred to boiled water bath for 30-40 minutes, then cooled and filtered through muslin cloth and centrifuged with speed of $3000 \mathrm{rpm}$ for 10 minutes. The two supernatants were mixed. Equal quantity of $\mathrm{N}$-propanol was added to the mixture prior to sodium chloride was added until the solution was separated into two layers. The lower layer extracted in separating funnel with Ethyl acetate, and concentrated by using rotary evaporator at $40^{\circ} \mathrm{C}$ for $1-2$ hours. The upper layer was dried by rotary evaporator at $40^{\circ} \mathrm{C}$ for $1-2$ hours. The dried material of both layers were mixed and dissolved in $5 \mathrm{ml}$ of $96 \%$ ethanol, then left in oven until it turned into powder and kept in refrigerator until use.

\section{TERPENOID}

Terpenoid were extracted according to the method of Harborne (1984). A quantity of $15 \mathrm{~g}$ of plant powder was successively extracted in a soxhlet extractor for 24 hours with $200 \mathrm{ml}$ chloroform. The solvent was removed by rotary evaporator at $40^{\circ} \mathrm{C}$. Then the extract, dried in the oven at $40^{\circ} \mathrm{C}$ until it turned into powder and kept in the refrigerator until use.

\section{ANIMALS}

Two hundred and ten male rats $(200-250)$ were obtained from the Medicine College Center / Al-Nahrain University. These animals were kept under suitable environmental conditions of $20-25^{\circ} \mathrm{C}$ in an air-conditioned room and light period of 12 hours daily. The animals were housed in plastic cages of dimensions $20 \times 50 \times 75 \mathrm{~cm}$ and had free access to water ad-libitum. The animals were kept for at least 2 weeks for adaptation before beginning the experiment.

\section{EXPERIMENTAL DESIGN}

\section{Castor Oil-induced Diarrhoea}

Thirty five rats were divided equally into seven groups and housed in seven cages containing five rats each. Rats in group A, which served as a positive control, received distal water only, in group B received $5 \mathrm{mg} / \mathrm{kg}$ of diphenoxylate hydrochloride and those in groups $\mathrm{C}, \mathrm{D}, \mathrm{E}$, and F received 
400, 20, 40, and $50 \mathrm{mg} / \mathrm{kg}$, of crude aqueous peel, phenols, alkaloid and terpenoid extract, respectively, the doses were selected on a trial basis, All administrations were orally. The rats were then housed singly in cages lined with white blotting paper. One hour after the above treatments, the rats were given $1 \mathrm{ml}$ of castor oil orally. The rats were observed at time intervals, up to $10 \mathrm{~h}$ after the castor oil administration, for the presence of diarrhoea. Diarrhoea, for the purpose of this study, was taken to mean watery (wet), unformed stool. The number of wet droppings was counted every hour for a period of $10 \mathrm{~h}$.(Shoba and Thomas, 2001).

\section{Anti-enteropooling Test}

Twenty five fasted rats were divided equally into five groups, five rats / group. Group A received distal water orally and served as control. Groups B,C, D and E received 400, 20, 40 , and $50 \mathrm{mg} / \mathrm{kg}$ orally of crude aqueous peel, phenols, alkaloid and terpenoid extract, respectively. The above treatments were given $1 \mathrm{~h}$ before administration of $1 \mathrm{ml}$. of castor oil orally. Intraluminal fluid accumulation was determined by the method of Robert et al., (1976). Two hours later, the rats were sacrificed, and the small intestine was ligated both at the pyloric sphincter and at the ileocecal junctions and dissected out. The small intestine was weighed. The intestinal contents were collected by milking into a graduated tube and the volume was measured. The intestines were reweighed and the differences between full and empty intestines were calculated.

\section{Gastrointestinal Motility}

Thirty rats were divided equally into six groups, five rats in each group. Charcoal food $(0.5 \mathrm{ml}$ of $5 \mathrm{~g}$ of activated charcoal suspended in $50 \mathrm{~mL}$ PSS) was given to five groups of five animals. In groups C, D, E and F, the charcoal food was administrated to animals intragastrically $60 \mathrm{~min}$ after orally administrated of crude aqueous peel, phenols, alkaloid and terpenoid extract (400, 20, 40, and $50 \mathrm{mg} / \mathrm{kg}$, respectively). Group B was treated with $1 \mathrm{mg} / \mathrm{kg}$ of atropine sulfate instead of the extract. Controls (group A) were treated with distal water before receiving the charcoal food. The rats were sacrificed one hour after the administration of the charcoal meal, the abdomen was opened and the small intestine was immediately isolated. The length of the intestine from the pylorus to the caecum (Length of Small Intestine (LSI)) and the distance traveled by the charcoal (Length of Charcoal Meal (LCM)) were measured. The peristaltic index (PI) for each rat was calculated, expressed as percentage of the distance traveled by the charcoal meal relative to the total length of the small intestine.

\section{Acute Toxicity Test}

Acute toxicity study was carried out using the method of Lorke (1983). One hundred and twenty rats were divided equally into twenty four groups, five rats / group. Six groups administered orally with $1000,1200,1400,1600,1800$, and
$2000 \mathrm{mg} / \mathrm{kg}$ for aqueous extract, six groups for Phenols, six groups for alkaloid and six groups for terpeniod crude peel extract of Punica granatum administered orally with $50,100,200,400,600$ and $800 \mathrm{mg} / \mathrm{Kg}$ body weight for phenols, alkaloid and terpenoid crude extract respectively. The rats were observed for signs of adverse effects and death for $24 \mathrm{~h}$ after treatment.

\section{Statistical Analysis}

Data were analyzed statistically using the Microsoft Program (SPSS). Statistical analysis of data was performed on the basis of Two-Way Analysis of Variance (ANOVA) using a significant level of $(\mathrm{P}<0.05)$. Specific group differences were determined using Least Significant Differences (LSD) as described by Snedecor and Cochran (1973).

\section{RESULTS}

\section{Extraction of Punica granatum}

Extraction of plant peels with distilled water gave a deep brown color extract with plant powder yield percentage of 3.3\%. The dry peels of Punica granatum, was extracted for detection of alkaloids, phenols and terpenoid. The yield of major compounds in each extracts was determined in Table 1.

Table 1: Compounds quantity yielded from plant expressed as $\%$

\begin{tabular}{|lll|} 
Plant & Type of extract & Yield \% \\
\hline Punica granatum peel & Crude aqueous & $3.3 \%$ \\
\cline { 2 - 3 } & Alkaloids & $12.5 \%$ \\
\cline { 2 - 2 } & Phenols & $25.4 \%$ \\
\cline { 2 - 2 } & Terpenoids & $5.2 \%$
\end{tabular}

This result is almost similar to the results of Qnais et al. (2007) who found that the percentage recovery of aqueous extract was $2.5 \%$ from $150 \mathrm{~g}$ of peels powder. The near similarity in yield percentage may be attributed to the same solvent which was used in the present extraction.

Results in Table 1 showed that the yield of phenols and alkaloids obtained from P. Granatum dry was higher (25.4\%, $12.5 \%)$ respectively than terpenoid extracts. This result is similar to obtained by Omulokoli et al. (1997) and Monica et al. (2013) they mentioned positive result for phenols and alkaloids presence in high level and referred noted differences between plant parts, alkaloids and flavonoids in peel and flower were high than seeds and leaves. Saponins were highly present in the peel, seeds and flower than leaves, tannin were highly present in peel, leaves and flower than seeds.

\section{Castor Oil-induced Diarrhoea}

In the hour following castor oil oral administration, control 
Table 2: The effect of Punica granatum peel extract, crude phenols, alkaloids and terpenoids extract on castor oilinduced diarrhoea in Rats

\begin{tabular}{llll} 
Groups & $\begin{array}{l}\text { Numbers of belts in } \mathbf{1 0} \text { hours } \\
\text { Mean } \pm \text { S.E }\end{array}$ & $\begin{array}{l}\text { Number of diarrhoeal belts } \\
\text { in 10 hours Mean } \pm \text { S.E }\end{array}$ & $\begin{array}{l}\text { Percent of } \\
\text { Inhibition }\end{array}$ \\
\hline Group A: + ve control & $18.6 \pm 0.03 \mathrm{a}$ & $17.4 \pm 0.6 \mathrm{a}$ & - \\
\hline Group B: Diphenoxylate Hydrochloride $5 \mathrm{mg} / \mathrm{kg}$ & $7.6 \pm 0.05 \mathrm{~b}$ & $3.8 \pm 0.8 \mathrm{c}$ & $78.1 \%$ \\
\hline Group C: PG extract $400 \mathrm{mg} / \mathrm{kg}$ & $9.8 \pm 0.06 \mathrm{~b}$ & $2.1 \pm 0.08 \mathrm{~cd}$ & $87.93 \%$ \\
\hline Group D: Crude Phenols extract $20 \mathrm{mg} / \mathrm{Kg}$ & $7.2 \pm 0.02 \mathrm{~b}$ & $0.0 \pm 0.0 \mathrm{~d}$ & $100 \%$ \\
Group E: Crude Alkaloids extract $40 \mathrm{mg} / \mathrm{Kg}$ & $9.2 \pm 0.5 \mathrm{~b}$ & $0.0 \pm 0.0 \mathrm{D}$ & $100 \%$ \\
Group F: Crude Terpenoids extract $50 \mathrm{mg} / \mathrm{Kg}$ & $8.3 \pm 0.05 \mathrm{~b}$ & $5.7 \pm 0.05 \mathrm{~b}$ & $67.24 \%$
\end{tabular}

Group rat $\mathrm{n}=5$ : Small letters refer to significant differences $(\mathrm{P}<0.05)$ among groups in the colums

Table 3: The effect of Punica granatum peel extract, crude phenols, alkaloids and terpenoids extract on castor oil-induced enteropooling in Rats

\begin{tabular}{|c|c|c|c|c|}
\hline \multirow[t]{2}{*}{ Groups } & \multicolumn{2}{|c|}{ Weight of intestinal content (g) } & \multicolumn{2}{|c|}{ Volume of intestinal content (ml) } \\
\hline & Mean \pm S.E & $\%$ of inhibition & Mean \pm S.E & $\%$ of inhibition \\
\hline Group A: +ve control & $2.45 \pm 0.07 \mathrm{a}$ & - & $1.74 \pm 0.06 \mathrm{a}$ & - \\
\hline Group B: $P . G$ extract $400 \mathrm{mg} / \mathrm{kg}$ & $0.7 \pm 0.04 \mathrm{~b}$ & $71.42 \%$ & $0.45 \pm 0.05 \mathrm{c}$ & $74.13 \%$ \\
\hline Group C: Crude Phenols extract $20 \mathrm{mg} / \mathrm{Kg}$ & $0.26 \pm 0.2 \mathrm{~d}$ & $89.3 \%$ & $0.22 \pm 0.08 \mathrm{~d}$ & $87.35 \%$ \\
\hline Group D: Crude Alkaloids extract $40 \mathrm{mg} / \mathrm{Kg}$ & $0.3 \pm 0.04 \mathrm{~cd}$ & $87.7 \%$ & $0.26 \pm 0.1 \mathrm{~d}$ & $84.48 \%$ \\
\hline Group E: Crude Terpenoids extract $50 \mathrm{mg} / \mathrm{Kg}$ & $0.93 \pm 0.09 \mathrm{~b}$ & $62.04 \%$ & $0.68 \pm 0.03 b$ & $60.91 \%$ \\
\hline
\end{tabular}

Group rat $\mathrm{n}=5$ : Small letters refer to significant differences $(\mathrm{P}<0.05)$ among groups in the colums.

group exhibited copious diarrhoea in $100 \%$ of the rats. Oral administration of phenols and alkaloids crude extract at 20 and $40 \mathrm{mg} / \mathrm{kg}$ respectively, induced a significant $(\mathrm{p}<0.05)$ antidiarrhoeal effect with the highest inhibition (100\%) against castor oil-induced diarrhoea for up to ten hours post-administration comparative with partial inhibition of diarrhoea $P$. granatum at dose $400 \mathrm{mg} / \mathrm{kg}$, which recorded (87.93\%). While the standard drug Diphenoxylate Hydrochloride exhibited $78.1 \%$ inhibition of defecation. Phenols and alkaloid crude extract showed considerable activity in prevention of diarrhoea, frequency of stooling (reduction in the number of wet stools and total stools), decrease in weight of wet stools and the general diarrhoea score including the hard, mild and copious diarrhoea (Table 2). Only in the first hour after castor oil administration terpenoid crude extract at $50 \mathrm{mg} / \mathrm{kg}$ has significant protection against induced diarrhoea and showed considerable activity in delaying in onset of diarrhoea. The phenols and alkaloid extract produced a significant $(\mathrm{p}<0.05)$ greater inhibitory effects on all the diarrhoea parameters investigated than the highest dose of the Punica granatum peel extract.

\section{Anti-EnTERopooling Test}

Castor oil induced accumulation of water and electrolytes intraluminal. Crude phenols and alkaloid extract at doses of 20 and $40 \mathrm{mg} / \mathrm{kg}$ reduction in intestinal weight and volume. Crude phenols and alkaloid extract produce $89.3 \%$ and $87.7 \%$ inhibition of weight, intestinal content respectively and volume of intestinal content was also reduced $87.35 \%$ and $84.48 \%$ with significance $(\mathrm{P}<0.05)$ when the
Punica granatum peel extract was compared compared to terpenoid at dose 400 and $50 \mathrm{mg} / \mathrm{Kg}$ respectively. Treatment with the crude phenols and alkaloid extract produced a significant and dose-dependent reduction in intestinal weight and volume of intestinal content. This may promote reabsorption of materials in the intestine due to decrease propulsion of material in the intestinal tract, and the extract might have exerted its antidiarrhoeal action by antisecretory mechanism. This result similar to obtained by Izzo et al. (1999) and Uchida et al. (2009).

\section{Gastrointestinal Motility}

Crude of phenols, alkaloid and terpenoid extract was tested on gastrointestinal motility by charcoal meal test. The percentage decrease in intestinal transit time caused by atropine sulphate, crude extract of phenols and alkaloid was $73.99 \%, 73.08 \%$ and $71.39 \%$ at a dose 1,20 and $40 \mathrm{mg} / \mathrm{kg}$ respectively.

These values are nonsignificant between them but significant $(\mathrm{p}<0.05)$ when compared with control group and Punica granatum peel extract and terpenoid. The result of Punica granatum peel extract and terpenoid shown that at doses of $400 \mathrm{mg} / \mathrm{kg}$ and $50 \mathrm{mg} / \mathrm{kg}$ caused a decrease in intestinal transit time by $59.42 \%$ and $56.17 \%$ respectively compared to control as shown in Table 4.

\section{Acute Toxicity Test of Aqueous Peels Extract} OF Punica granatum

In the acute toxicity studies of oral administration of the aqueous peel extract, phenols, alkaloids and terpenoid 
Table 4: Effect of Punica granatum peels extract, crude phenols crude alkaloids and crude terpenoids extract on intestinal motility expressed as distance traveled by the charcoal food as percent of the total intestinal length

\begin{tabular}{lllll} 
Groups & $\begin{array}{l}\text { Total length of small } \\
\text { intestine }(\mathbf{c m})\end{array}$ & $\begin{array}{l}\text { Distance of } \\
\text { transverse (cm) }\end{array}$ & Peristaltic Index & $\begin{array}{l}\text { Percent of } \\
\text { inhibition }\end{array}$ \\
\hline Group A: +ve control & $97.4 \pm 0.83 \mathrm{a}$ & $76.9 \pm 0.60 \mathrm{a}$ & $78.15 \pm 0.1 \mathrm{a}$ & $100 \%$ \\
\hline Group B: Atropine sulphate $1 \mathrm{mg} / \mathrm{kg}$ & $96.8 \pm 0.07 \mathrm{a}$ & $20 \pm 0.01 \mathrm{~d}$ & $20.66 \pm 0.02 \mathrm{~d}$ & $73.99 \%$ \\
\hline Group B: $P . G$ extract $400 \mathrm{mg} / \mathrm{kg}$ & $95 \pm 0.04 \mathrm{a}$ & $31.2 \pm 0.07 \mathrm{c}$ & $32.84 \pm 0.04 \mathrm{c}$ & $59.42 \%$ \\
Group C: Crude Phenols extract $20 \mathrm{mg} / \mathrm{Kg}$ & $92 \pm 0.71 \mathrm{a}$ & $20.7 \pm 0.08 \mathrm{~d}$ & $22.5 \pm 0.07 \mathrm{~d}$ & $73.08 \%$ \\
\hline Group D: Crude Alkaloids extract $40 \mathrm{mg} / \mathrm{Kg}$ & $93.5 \pm 0.26 \mathrm{a}$ & $22 \pm 0.05 \mathrm{~d}$ & $23.52 \pm 0.03 \mathrm{~d}$ & $71.39 \%$ \\
Group E: Crude Terpenoid extract $50 \mathrm{mg} / \mathrm{Kg}$ & $94.8 \pm 0.75 \mathrm{a}$ & $33.7 \pm 0.06 \mathrm{~b}$ & $35.45 \pm 0.05 \mathrm{~b}$ & $56.17 \%$
\end{tabular}

Group rat $\mathrm{n}=5$ : Small letters refer to significant differences $(\mathrm{P}<0.05)$ among groups in the colums

crude extract of Punica granatum none of the animals showed behavioral, neurological or physical changes. In addition, no mortality was observed at the test dose. Thus, the median lethal dose (LD50) of the plant extract was found to be greater than $2000 \mathrm{mg} / \mathrm{Kg}$.

\section{DISCUSSION}

Orally administered castor oil at a dose of $1 \mathrm{ml}$ induced diarrhoea after one hour, the reason for that is castor oil is known for its laxative effects due to its active component, retinoic acid. Castor oil is characterized by a high content about $90 \%$ of the hydroxylated unsaturated fatty acid ricinoleic acid mainly responsible for diarrhoea production (Ramakrishna et al., 1994). Ricinoleic acid is released by lipases in the intestinal lumen after oral ingestion of castor oil, and higher amounts of ricinoleic acid are absorbed in the small intestine and increases the peristaltic activity of the small intestine as a result of permeability of $\mathrm{Na}^{+}$and $\mathrm{Cl}$ changed in the intestinal mucosa (Qnais et al., 2007). The result of the current study is in agreement with (Mckeon et al., 1999; Palombo, 2006) who showed an induced diarrhoea after oral ingestion of castor oil.

Yoshio et al. (1999) and Oben et al. (2006) emphasize that ricinoleate could stimulat the secretion of endogenous prostaglandin like Prostaglandins E and F which are considered to be good diarrheogenic agents in experimental animals as well as in human beings. The active metabolite recinoleic acid in castor oil induces diarrhoea due to changing the electrolyte permeability by increasing electrolytes secretion, of the intestinal membrane, decreaseing electrolytes absorption, and deranging intestinal motility causing a decreased transit time in addition to increased luminal osmolarity (osmotic diarrhoea) through elevating biosynthesis and releaseing of prostaglandin which causes diarrhoea similar to some pathophysiologic conditions. This result confirms those of (Galvez et al., 1993; Besra et al., 2002; Agbor et al., 2004; Brijesh et al., 2009; Gutiérrez et al., 2013).

Other causes of diarrhoea due to castor oil are decreased fluid absorption by inhibiting intestinal $\mathrm{Na}$, K ATPase activity and increased secretion in the small intestine and colon, and affected smooth muscle contractility in the intestine, as reported by (Phillips et al., 1965; Nell and Rummel, 1984). In addition to activation of adenylylcyclase or mucosal cAMP mediated active secretion, and stimulation of endogenoeus prostaglandins $\mathrm{E}$ and $\mathrm{F}$ which causes stomach cramp and diarrehrea. Recnetly, platelet-activating factor and nitric oxide was contributed to the diarrhoea effect of castor oil as described by (Capasso et al., 1992; Galvez et al., 1993; Capasso et al., 1994; Mascolo et al., 1996; Uchida et al., 2000). The crude of phenols, alkaloids and aqueous extract of Punica granatum peels was evaluated for anti-diarrhoeal activity with less side effect than the conventional drug. The crude of phenols, alkaloids and aqueous extract of Punica granatum peels shows antidiarrhoeal activity by reducing gastrointestinal motility and intestinal fluid accumulation. The antidiarrhoeal activity of Punica granatum peels extract could be returned to several mechanisms like the extract may increase the reabsorption of water and $\mathrm{NaCl}$ by reducing intestinal motility or it may reduce mucosal secretion and prevent prostaglandin release from intestinal mucosa.

The main chemical constituents in Punica granatum peels extract responsible for antidiarrhoeal activity are tannins, phenols, alkaloids, flavonoids and terpenoid by increasing colonic water and electrolyte reabsorption and inhibiting intestinal motility. This was affirmed by Farthing et al. (2008) and Daswani et al. (2010) who stated that the presence of the active ingredients particularly phenols, alkaloids, and terpenoid in the plant extract gave high activity in the inhibition of diarrhoea cases and the decrease of peristaltic index and it was similar to diphenoxelyte hydrochorid. Morever, giving the aqueous Punica granatum peels extract and the crude of phenols, crude alkaloids and crude terpenoid extracts made reduction of total number of wet feces in the test groups of the experiment and this decrease was dose dependent and this might be due to the extract and the active ingredient which worked through the reduction of prostaglandins secretion from intestinal mucosa. 
Liberation of ricinoleic acid by castor oil results in irritation and inflammation of intestinal mucosa, which lead to the release of prostaglandins and stimulation of intestinal secretion this was evident in the concentration of phenloe $(20 \mathrm{mg} / \mathrm{Kg})$ and alkaloid $(40 \mathrm{mg} / \mathrm{Kg})$ and aqueous extract of Punica granatum peel $(400 \mathrm{mg} / \mathrm{Kg})$ inhibitors of prostaglandins biosynthesis are therefore considered to inhibit and delay castor oil-induced diarrhea. These results are in agreement with Ramakrishna et al. (1994), Qnais et al. (2007) and Sorin et al. (2012) who confirmed delay castor oil-induced diarrhoea as a result to inhibition of prostaglandin biosynthesis.

Prostaglandins are associated with changes in the bowel that stimulate diarrhoea. A recent study shows that the laxative effect of ricinoleic acid present in castor oil is due to the induction of contraction of intestinal smooth muscle which is mediated by activation of EP3 receptors on intestinal smooth-muscle (Brijesh et al., 2009). The P.granatum peels extracts and active ingredient exhibited insignificant inhibitory activity against castor oil induced diarrhoea at all doses. The results were dose dependent and comparable with that of standard drug as diphenoxelyte hydrochorid.

The therapeutic effect of diphenoxelyte hydrochorid is believed to be due to its anti-motility and anti-secretory properties. The mechanisms of anti-secretory action of diphenoxelyte hydrochorid have been discussed with reference to opiate agonism, block of calcium channels, and inhibition of calmodulin (Suzuki et al., 2000). From our results, it is likely that P.granatum peels extracts may mediate its effects through similar mechanisms.

The extract treated animals showed significant inhibitory activity against castor-oil induced diarrhoea and PGE2 induced enteropooling in rats. It is widely reported that different antidiarrhoeal agents exert their effect through different mechanisms such as inhibiting secretion, decreasing motility, delaying intestinal transit, reducing intraluminal fluid accumulation or by enhancing water absorption (Chitime, 2004; Abu Mohammed et al., 2013; Njinga et al., 2013). The crude of phenols, alkaloids and extract of P.granatum peels extracts produced an insignificant increase or decrease in propulsive movement at the standard charcoal meal in the small intestine, respectively suggesting a weak spasmolytic activity. This activity was reverse dose dependent. The result of this experiment could be due to two types of receptors which appeared to be involved in extracts action on gastrointestinal tract: high and low affinity receptor subtypes sensitive to low and high agonist concentrations, which induced contraction and relaxation of smooth muscles respectively as found by Rouf et al. (2007) and Jalilzadeh-Amin et al. (2012) that the effect of aqueous peel extract is dose depended. Therefore, prob- ably P.granatum peels extracts at low doses increased the reabsorption of $\mathrm{NaCl}$ and water by decreasing intestinal motility as observed by the decrease in intestinal transit by charcoal meal and by their anticholinergic and antihistaminic effects. This agreed with De Urbina et al. (1990) and Brankovic et al. (2009). The plant extract inhibited normal gastric emptying; this effect may be linked to the reduction in gastrointestinal propulsion observed in the rats. (Izzo et al., 1999; Camilleri, 2004; Uchida et al., 2009) showed decrease in intestinal transit time by morphine and atropine is linked to delays in gastric emptying. This suggests that the plant may have morphine-like action in exerting its antidiarrhoeal activity. The antidiarrhoeal activity of aqueous plant extract and active ingredient by using different dose level through regulating the gastrointestinal tract, slow down transit in the intestine, reduce colon flow rates and consequently have any effect on colonic motility this result is in support of previous claims in respect of antidiarrhoeal herbs.

\section{CONCLUSION}

The present study also confirms the presence of phenols, alkaloids, terpenoid in $P$. granatum is potential therapeutic option in the effective management of diarrhoea, thus justifying its widespread use by the local population for these purposes. Flavonoids and alkaloids more effective than terpenoid for inhibiting release of autacoids and prostaglandins, thereby inhibit secretion induced by castor oil. The given antidiarrhoeal activity of the rind extract of $P$. granatum may be due to the presence of previously mentioned phytochemicals present. It may be concluded that the present study supports the traditional use of the rind or aqueous extract of $P$ granatum by traditional medical practitioners in the treatment of diarrhoea and associated disorders.

\section{ACKNOWLEDGEMENT}

The authors are thankful to the Department of Physiology and Pharmacology, Baghdad University, for giving consent and support to carry out this study.

\section{CONFLICT OF INTEREST}

No any conflict of interest.

\section{AUTHORS CONTRIBUTION}

Through the availability of the fruit of the pomegranate and its benefits in preventing many diseases, including diarrhea, it came the idea of a researcher at extracting the active ingredients and study of the effect in preventing diarrhea. 
-Abu Mohammed TI, Muhammad EU, Asharf UC, Mominur R, Razibul H, Atiar R (2013). In vivo antidiarrhoeal and cytotoxic potential of different fractions of Pandanus Foetidus leaves. Am. J. Biomed. Sci. 5(Suppl 3): 208-216.

-Agbor GA, Léopold T, Jeanne NY (2004). The antidiarrhoeal activity of Alchornea cordifolia leaf extract. Phytother. Res. 18: 873-876. http://dx.doi.org/10.1002/ptr.1446

-Agunu A, Ahmadu AA, Afolabi SO, Yaro AU, Ehinmidu JO, Mohammed Z (2011). Evaluation of the antibacterial and antidiarrhoeal activities of Heeria insignis O. Ktze. Indian. J. Pharm. Sci. 73(Suppl 3): 328-332.

-Arun N, Singh DP (2012). Punica granatum: a review on pharmacological and therapeutic properties. Int. J. Pharma. Sci. Res. 3(5): 1240-1245.

-Besra SE, Gomes A, Chaudhury L, Vedasiromoni JR, Ganguly DK (2002). Antidiarrhoeal activity of seed extract of Albizzia lebbek Benth. Phytother. Res. 16: 529-533. http:// dx.doi.org/10.1002/ptr.961

-Brankovic SV, Kitic DV, Radenkovic MM, Veljkovic SM, Golubovic TD (2009). Calcium blocking activity as a mechanism of the spasmolytic effect of the essential oil of Calamintha glandulosa Silic on the isolated rat ileum. Gen. Physiol. Biophys. 28: 174-178.

-Brijesh S, Daswani P, Tetali P, Antia N, Birdi T (2009). Studies on the antidiarrhoeal activity of Aegle marmelos unripe fruit: Validating its traditional usage. BMC Complement. Altern. Med. 9(Suppl 47): 1-12. http://dx.doi.org/10.1186/14726882-9-47

-Brown JH, Taylor P (1996). Muscarinic receptor agonists and antagonist. In: Hardman JG, Limbird LE, editors. Goodman and Gilman, the pharmacological basis of therapeutics. 9th ed. New York: McGraw Hill. Pp. 148-154.

-Bruton L (1996). Agents affecting gastrointestinal water flux and motility, digestants and bile acids. In: Pharmacological basis of therapeutics, 9th edn., McGraw-Hill, New York, Pages 916.

- Camilleri M (2004). Chronic diarrhoeal: A review of pathophysiology and management for the clinical gastroenterologist. Clin. Gastroenterol. Hepatol. 2: 198. http://dx.doi.org/10.1016/S1542-3565(04)00003-5

- Capasso F, Mascolo N, Izzo AA, Gaginella TS (1994). Dissociation of castor oil-induced diarrhoea and intestinal mucosal injury in rat: Effect of NG nitro-L-arginine methylester. Br.J. Pharmacol. 113: 1127-1130. http://dx.doi. org/10.1111/j.1476-5381.1994.tb17113.x

- Capasso F, Tavares IA, Bennet A (1992). PAF formation by human gastrointestinal mucosa/ submucosa in vitro: release by ricinoleic acid, and inhibition by 5 -aminosalicylic acid. J. Pharm. Pharmacol. 44: 771- 772. http://dx.doi. org/10.1111/j.2042-7158.1992.tb05518.x

- Chitime HR (2004). Studies on antidiarrhoeal activity of Calotropis gigantean R.H. in experimental animals. J. Phar. Pharm. Sci. 7(Suppl 1): 70-75.

-Daswani PD, Brijesh S, Tetali P, Antia NH, Birdi TJ (2010). Antidiarrhoeal activity of Zingiber officinale (Rosc.). Curr. Sci. 98 (2): 222-229.

-De Urbina AVO, Martin MLM, Montero J, Carron R, San Roman L (1990). Antihistiminic activity of pulegone on the guinea-pig ileum. J. Pharm. Pharmacol. 42: 295-296. http:// dx.doi.org/10.1111/j.2042-7158.1990.tb05414.x

-El-Nemr SE, Ismail IA, Ragab M (1990). Chemical composition
- Farthing M, Lindberg G, Dite P, Khalif I, Salazar LE, Ramakrishna BS, Goh K, Thomson P, Khan AG (2008). World Gastroenterology Organisation practice guideline: Acute diarrhoea. Pp. 1-29.

- Gaginella TS, Stewar JJ, Olsen WA, Bass P (1975). Action of recinolic acid and structurally related fatty acid on the GI tract. II. Effect on water and electrolytes absorp-tion invitro. J. Pharmacol. Exp. Therapeutic. 195: 355-356.

- Galvez J, Zavzuelo A, Crespo ME, Lorente MD, Ocete MA, Jimenez J (1993). Anti-diarrhoeic activity of Euphorbia hirta extract and isolation of an active flavonoids constituent. Planta. Med. 59: 333-336. http://dx.doi. org/10.1055/s-2006-959694

- Galvez J, Zavzuelo A, Crespo M.E, Lorente MD, Ocete MA, Jiménez J (1993). Antidiarrhoeic activity of Euphorbia hirta extract and isolation of an active flavonoid constituent. Planta. Med. 59: 333-336. http://dx.doi. org/10.1055/s-2006-959694

-Ghani A (2003). Medicinal Plants of Bangladesh: Chemical Constituents and Uses. 2nd ed. Dhaka, Bangladesh: The Asiatic Society of Bangladesh.

-Gurib-Fakim A (2006). Medicinal plants: traditions of yesterday and drugs of tomorrow. Mol. Aspects. Med. 27:1:93.

- Gutiérrez SP, Sanchez MAZ, Gonzlalez CP, Garcia LA (2013). Antidiarrhoeal activityof different plants used in traditional medicine. Afr. J. Biotechnol. 6(Suppl 25): 2988-2994.

-Harborne JB (1984). Phytochemical methods. Chapman and Hall. New York 2nd ed. Pp. 288. http://dx.doi. org/10.1007/978-94-009-5570-7

-Izzo AA, Mascolo N, Capasso R,Germano MP, De pasuele R, Capasso F (1999). Inhibitory effect of cannabinoid agonists on gastric emptying in rat. Arch. Pharmacol. 360: 221-223. http://dx.doi.org/10.1007/s002109900054

-Jalilzadeh-Amin G, Maham M, Dalir-Naghadeh B, Kheiri F (2012). Effects of Mentha longifolia essential oil on ruminal and abomasal longitudinal smooth muscle in sheep.J. Essent. Oil. Res. 24: 61-69. http://dx.doi.org/10.1080/10412905.20 12.646019

-Lorke D (1983). A new approach to tropical acute toxicity testing. Arch. Toxicol. 53: 275-287. http://dx.doi.org/10.1007/ BF01234480

-Mascolo N, Izzo AA, Gaginella TS, Capasso F (1996). Relationship between nitric oxide and platelet-activating factor in castor-oil induced mucosal injury in the rat duodenum. Naunyn Schmiedebergs Arch. Pharmacol. 353: 680-684. http://dx.doi.org/10.1007/BF00167187

-Mckeon TA, Lin JJ, Stafford AE (1999). Biosynthesis of ricinoleate in castor oil. Adv. Exp. Med. Biol. 464: 37-47. http://dx.doi.org/10.1007/978-1-4615-4729-7_4

-Meite S, N'guessan DJ, Bahi C, Yapi FH, Djaman AJ, GuedeGuina F (2009). Anti-diarrhoeal activity of the ethyl acetate extract of morinda morindoides in rats. Trop. J. Pharm. Res. 8(Suppl 3): 201-207. http://dx.doi.org/10.4314/tjpr. v8i3.44533

-Monica Viladomiu, Raquel, Hontecillas, Pinyi Lu, Bassaganya J (2013). Preventive and Prophylactic Mechanisms of Action of Pomegranate Bioactive Constituents. Article ID 789764, 18 pages. http://dx.doi.org/10.1155/2013/789764

- Navindra PS, Susanne M, Henninga YZ, Marc S, Daved H (2006). Pomegranate juice ellagitanin metabolites are present in human plasma and som persist in urine for up to 48 hours. J. Nutr. 136: 2481-2485. 
-Nell G , Rummel W (1984). Action mechanism of secretagogue drugs. In: Csaky TZ (Ed.), Pharmacology of Intestinal Permeation, second ed. Springer-Verlag, Berlin. Pp. 461508. http://dx.doi.org/10.1007/978-3-642-69508-7_12

- Njinga NS, Sule MI, Pateh UU, Hassan HS, Usman MA, Haruna MS (2013). Phytochemical and antidiarrhoea activity of the Methanolic Extract of the Stem Bark of Lannea kerstingii Engl. and K. Krause (Anacardiaceae). J. Nat. Prod. Plant. Resour. 3(Suppl 3): 43-47.

- Oben JE, Assi SE, Agbor GB, Musoro DF (2006). Effect of Eremomastax speciosa on experimental diarrhoea. Afr. J. Tradit. Complement. Altern. Med. 3(1): 95- 100.

-Omulokoli E, Khan B, Chhabra SC (1997). Antiplasmodial activity of four Kenyan medicinal plants. J. Ethnopharmacol. 56: 133-137. http://dx.doi.org/10.1016/S03788741(97)01521-3

-Palombo EA (2006). Phytochemicals from traditional medicinal plants used in the treatment of diarrhoea: modes of action and effects on intestinal function. Phytother. Res. 20(Suppl 9): 717-724. http://dx.doi.org/10.1002/ptr.1907

-Phillips RA, Love AUG, Mitchell G, Neptune EM (1965). Cathartics and the sodium pump. Nature 206: 1367-1368. http://dx.doi.org/10.1038/2061367a0

- Qnais EY, Elokda AS, Abu Ghalyun YY, Abdulla FA (2007). "Antidiarrhoeal Activity of the Aqueous Extract of Punica granatum (Pomegranate) Peels” Pharm. Biol. 45(9): 715720. http://dx.doi.org/10.1080/13880200701575304

-Ramakrishna BS, Mathan M, Mathan VI (1994). Alteration of colonic absorption by long-chain unsaturated fatty acids, influence of hydroxylation and degree of unsaturation. Scandinavian J. Gastroenterol. 29: 54-58. http://dx.doi. org/10.3109/00365529409090437

-Ribereau-Gayon P (1972). Plant phenols. Oliver and Boyd. USA. Pp. 254.

-Robert A, Nezamis JE, Lancaster C, Hanchar AJ, Klepper MS (1976). Enteropooling assay, a test for diarrhoea produced by prostaglandins. Prostagladins. 11: 809-828.

-Rouf R, Uddin SJ, Alamgir M (2007). Assessment of antidiarrhoeal activity of the methanol extract of Xylocarpus granatum bark in mice model. J. Ethnopharmacol. 109: 539-

542. http://dx.doi.org/10.1016/j.jep.2006.08.015

- Shoba FG, Thomas M (2001). Study of antidiarrhoeal activity of four medicinal plants in castor oil-induced diarrhoea. J. Ethnopharmacol. 76: 73-76. http://dx.doi.org/10.1016/ S0378-8741(00)00379-2

- Snedecor GW, Cochra WG (1973). Statistical Methods. 6th ed. Iowa state University press. USA. Pp. 238-248.

- Sorin T, Till FA, Rolf MN, Martin D, Stefan O (2012). Castor oil induces laxation and uterus contraction via ricinoleic acid activating prostaglandin EP3 receptors. Proc. Natl. Acad. Sci. USA 109(23): 9179-9184. http://dx.doi.org/10.1073/ pnas. 1201627109

-Suzuki T, Sakai H, Ikari A, Takeguchi N (2000). Inhibition of thromboxane A2-induced CL2 secretion by antidiarrhoea drug loperamide in isolated rat colon. J. Pharmacol. Exp. Ther. 295: 233-238.

-Thankurta P, Bhowmik P, Mukjerjee S, Hajra T, Patra A, Bag P (2007). Antibacterial, antisecretory and antihemorrhagic activity of Azadirachta indica used to treat cholera and diarrhoea in India. J. Ethnopharmacol. 111(Suppl 3): 607612. http://dx.doi.org/10.1016/j.jep.2007.01.022

-Uchida M, Yoshida K, Shimizu K (2009). Effect of atropine sulfate on gastric emptying and gastrocecal transit time evaluated by using the [1_13C] acetic acid and lactose [13C] ureide breath test in conscious rats. J. Breath. Res. 3(4): 7003. http://dx.doi.org/10.1088/1752-7155/3/4/047003

-Uchida M, Kato Y, Matsuede K, Shode R, Muraoka A, Yemato S (2000). Involvement of NO from nerves in diarrhoea induced by castor oil in rats. Jpn. J. Pharmacol. 82: 168-170. http://dx.doi.org/10.1254/jjp.82.168

-World Health Organization: Water and Sanitation. Geneva, Switzerland: WHO, 1996. Volume 12.

-Yoshio K, Kazuko S, Bunsyo M, Kazunori H, Atsushi I, Yasuhiro K (1999). Relationship between antidiarrhoeal effects of Hange-Shashin-To and its active components. Phytother. Res. 13: 468-473. http://dx.doi.org/10.1002/(SICI)10991573(199909)13:6<468::AID-PTR504>3.0.CO;2-V

- Zakir R (2005). Pomegranate Extract and determination of content. J. Nutr. Biochem. 55: 180-120. 